\title{
Journey to a Land of Cotton: A Slave Plantation in Brooklyn, 1895
}

\section{Lori L. Brooks}

Billed as a "Panorama of the Negro," Nate Salsbury's 1895 Black America pageant commemorated the social evolution of blacks from "the Jungles of Africa to the Civilization of America." The pageant integrated the civic drama of historical pageantry, the commercialism of the variety show, and the educational imperatives of the ethnographic exhibition. Urban northerners were transported to the "sunny South" of the antebellum era, a rigidly hierarchical world where "cotton was king." Audiences milled around the "slave village," a temporally and spatially displaced "plantation" in Brooklyn's Ambrose Park with a guidebook that drew their attention to "characteristic" scenes of remarkable verisimilitude: a slave quarter buzzing with neighbors out "visiting," the scent of poultry and livestock, and the blooms of a realistic cotton "field" (whose bolls were held up with sticks and wire). ${ }^{2}$ Nearby, a group of black southern laborers processed and baled cotton in a mule-powered gin. In the evening, Black America featured a variety showcase of songs, dances, and customs said to be typical of black southern folk. Vocal soloists, sixty-three vocal quartets, and a plethora of choral ensembles evoked the Old South with familiar songs like "My Old Kentucky Home" and less familiar ones like "The Cabin Where I Was Born" and "Ham Bone Am Sweet" while dancers demonstrated folk dances like the "heel and toe" and the "buck and wing." As a grand finale, the faces of the "immortal friends of the bondsmen"- John Brown, Abraham Lincoln, Ulysses Grant, General Sherman, and Harriet Beecher Stowe-were displayed "in he- 
roic size" as the choir sang "America" in the background. As the anthem rose beneath Lincoln's "mute and benign countenance," one misty-eyed witness believed the image of the "Great Emancipator" to be especially fitting since it was he, the observer noted, who had made "a country for blacks where before it had been only an abiding place." 3

A master of outdoor entertainments, most Americans knew the pageant's white manager Nate Salsbury from his wildly successful Buffalo Bill Wild West Show. Black America has been largely forgotten, despite being one of the biggest outdoor shows of its time. Its popularity and contradictory message of progress and pacification reflected an era of racial retrenchment. ${ }^{4}$ Salsbury recruited nearly five hundred black southerners from Virginia and North and South Carolina who replaced the "show Indians" of the Wild West Show, now on tour. Salsbury hoped his new show would redress the financial damage caused by the Panic of 1893 and the steep overhead required for a cast of hundreds. ${ }^{5}$ Black America's nostalgic depiction of the African American past willfully ignored the brutally inhumane "unfreedom" of slavery, indulging instead in a nostalgic view of slavery as a beneficent institution, a stopover in the transition between African barbarism and industrial modernity. The show aimed to portray "the peculiarities of the Southern negro in a manner that most Northern persons have never been able to observe." "We see the negro himself," the Brooklyn Daily Eagle excitedly announced, "the American citizen, and the colored voter, in the process of evolution. ... We get glimpses of the working of his mind, learn what appeals will move him and in what lines he is most likely to make progress." 7

What was the public's investment in identifying the African American performers in Black America as individuals devoid of the artifice that commercial entertainment entailed, in other words, to see them billed as "the real thing" rather than actors and artists performing for a paying audience? What satisfactions did such investments in black "naturalism" provide for its white audiences? Outside the pageant's walls, African Americans arrived in New York City in ever-greater numbers in search of the social and political equality unavailable to them in the South. Once settled, this population began to chafe publicly against the deeply entrenched forms of northern discrimination. In the same year as Salsbury's pageant, African Americans in the state celebrated the passage of a Civil Rights Act, legislation that disrupted the perceived racial "peace" of the city in 1895, exposing the long history of antiblack discrimination in New York and the mechanisms of northern urban racism functioning silently and efficiently in the background. Accused of ingratitude, black New Yorkers endured a very public backlash by white business owners who adamantly refused to jeopardize their businesses by obeying equal access laws. Only a year later, the Supreme Court would provide legal sanction for racial segregation with Plessy v. Ferguson, making the pageant's rather liberal presentation of African American progress from slave to "citizen" even more paradoxical. Salsbury's promotional strategies and coverage by the local white press reveal how Black 
America served as an opportunity to reimagine the antebellum era's rigid racial hierarchies in the urban North at the turn of the century. The pageant became a way for northerners to symbolically mourn the loss of the "docile" slave, a fictive figure but one who bore little resemblance to the race's modern descendants.

The pageant's nostalgic national vision staged a past in which racial difference had coherence and a sense of clarity about race and space that were, by the end of the century, undergoing a major transition. By couching blackness within regressive tropes of history and contemporary industrial progress, Black America sought to solidify these notions of race as part of the collective national historical memory. In this article, I explore the racial discourse of Black America and the ways by which the pageant created an opportunity for both African Americans and whites in New York to "speak back" to Salsbury's nostalgic racial discourse. The pageant's invocation of spatiality and temporality said more, I insist, about the presence of blacks in northern urban centers than about the antebellum South and, despite its rather liberal view of black history, served as a medium to discuss local racial anxieties, not only the entrenched racial status quo but also local white concerns about the growing black population of turn-of-the-century New York City. As Michelle Wallace has argued, the concrete realities of Jim Crow segregation must be located in the aesthetics, narratives, and forms of an era's cultural production. ${ }^{8}$ By couching blackness within regressive tropes of history and thus placing it in service to contemporary industrial progress, Black America sought to solidify ideologies of race within the collective national historical memory. ${ }^{9}$

As Susan Stewart argues, nostalgia is rooted in a denial of the present and as such more accurately represents "a collage made of presents" than "a reawakening of a past." ${ }^{\text {"10 }}$ Racial formations and nostalgia function in tandem, enabling one to imagine and, ideally, to live in a present according to the racial epistemologies of another era, a present seemingly authorized by that history and its fictions of purity. Stewart argues that nostalgia- "the longing for an impossibly pure context of lived experience"-is ideological, utopic, and ultimately "a sadness without an object" (or "the desire for desire"). Black America emphasized scale and proportion and commemorated race and national history as the "desire for desire." The pageant's epic reach offers an example of how proportion transforms the communal experience of "historical" objects and practices. Stewart observes that notions of the pastoral rely on the grandiosity of the natural world's production of "individual perceiving consciousness" while the gigantic proportions of industrialism enlarge the scale of the body in relation to the natural world, making it always only partially perceptible to the individual. In this sense, the scale of New York City was itself integrated into the performance as well as the pageant's incongruous pastoral and historical relationship to this city, becoming central to the experience of the pageant. With the incorporation of neighboring boroughs, the city's expanding boundaries made it officially the "Empire City" in 1898. Set apart from the "city" proper, 
the pageant's "park" setting in Brooklyn created a sense of spatial separation from Manhattan, an "epic" model of both urban industrialism and a center of global finance center. Even as the pageant's pastoralism relied on the cultivation of a certain type of interiority within the individual (i.e., a sense of comparative "smallness"), the epic proportions of the antebellum plantation and its "beehive" of black workers served as a model of the "social world of material production" that Stewart argues is central to industrial capitalism's enormity of scale. ${ }^{11}$ The "gigantic," as Stewart notes, enables movement "from a presocial world of the natural to a social world of material production." 12 And Salsbury's massively sized performance companies, indulgent temporal reach, and grandiose spatial scale animated the nostalgic tone of his production.

Both the ideological workings of pastoralism and industrialism were in operation in the pageant. Black slave labor, Salsbury's pageant suggested, had contributed tremendously to the national economy and would continue into the future. Black America created a narrative thread connecting "King Cotton's" slaves to late nineteenth-century sharecroppers and other forms of "unfree" agricultural labor serving the modern industrial cotton market. Such reliance on a nostalgia of place and time - the South and the antebellum past - served as a cultural fulcrum, a static metaphor, whose historical presence, as Daphne A. Brooks has demonstrated, stabilized imperialist ideologies and reassured whites of their superiority. ${ }^{13}$ The pageant served as a spectacle of North-South reconciliation, commemorating antebellum economic ties between the two regions with the central argument that turn-of-the-century southern agriculture and northern industry needed one another and that the greater economic progress of the nation relied on relinquishing any lingering historical resentments. For this reason, the presence of Salsbury's pageant in New York City-the commercial center of the United States as well as one of the most important cotton markets in the world - was key. Any notion that Salsbury's use of blacks as a type of industrial vanguard must be tempered, however, with an awareness that black "territories," bodies, and expressive cultures, as Jayna J. Brown has demonstrated, have historically been co-opted by whites as symbols of "modernity," often as a means to rejuvenate and define white racial formations. ${ }^{14}$

Late nineteenth-century Americans were more familiar with Salsbury's earlier success with Buffalo Bill's Wild West Show and its dramatization of the violent encounters between Indians and whites on the western frontier. The Wild West Show featured a tribally indistinct combination of native peoples"show Indians" - and other western types in equestrian feats and embellished "reenactments" of what were said to have been actual skirmishes on the western plains. Promoted as an authentic depiction of life in the "wild West," Salsbury's first epic commercial venture featured mock military battles between whites and Indians and feats of horsemanship and marksmanship by unconventional western figures like the trick-shooter Annie Oakley. As Joy Kasson has shown, the show's originality relied not only on its claims to authenticity but also, more importantly, on Salsbury and Cody's presentation of the living history of the 
Old West on a grand scale. Salsbury transformed popular memory into a commercial force by embedding "the central features of the show in a historical and ethnological narrative." ${ }^{\prime 2}$ Before collaborating with Salsbury to create what would become known as Buffalo Bill's Wild West Show, William "Buffalo Bill" Cody had already brought his own experiences as an Indian scout in the West to the popular stage as a small-time actor. Cody blurred the line between reality and fiction, embellishing his western adventures and positioning himself-and therefore Anglo-Americans - as the ultimate victors in the march west. As Kasson has argued, Cody was the first American "celebrity," marketing himself as a living "biography of the Middle West." For many white Americans of his era, he embodied a virile, heroic Anglo-American masculinity perceived to be (like frontier itself) rapidly falling victim to "over-civilization." ${ }^{\prime 6}$ Like Black America, the Wild West Show was, in Salsbury's hands, a tidily packaged commodity rooted in a mythic, highly flawed narrative of U.S. history. Structurally, the transition from the Wild West Show to the Black America pageant was fairly uncomplicated: Salsbury dismantled the western tent city and twenty-foot-high painting of the Big Horn Mountains and replaced them with a hundred log cabins and giant images of famous abolitionists.

\section{"They Are as the Lord Made Them": Space, Time, and Nostalgia in Race Making}

Like the Wild West Show, Black America related a heroic national narrative through the history of its most denigrated citizens and, in doing so, put historicized racial tropes of blackness in service to a hegemonic national narrative. Here, blacks rather than Indians served as raw material for turn-of-thecentury popular commercial culture. Doing double duty as temporal as well as spatial markers, such racial tropes moved contradictorily between hackneyed antebellum plantation romances and minstrelized parodies of African American culture found in Tin Pan Alley "coon songs" of the era. In Salsbury's sympathetic liberal narratives, the past became a racial allegory, one in which African Americans served as nation builders and emblematic citizens. The slavery theme functioned as an ironic model of social order and civic virtue, depicting black plantation workers as a labor force disciplined by industrial morality and paternalistic hierarchy. Rooted in the cultural and narrative act of remembering, Black America's mammoth scale lent form to the desire for an authentic past characterized by both specialized craftsmanship and large-scale productivity, a vision of communal village life that functioned anachronistically alongside mass-scale agricultural production.

As the press noted, one could witness Black America on two different days and experience an entirely different production each time because the participants were not actors; rather, they were "the natural production of [the South]," called on to simply "act naturally." 17 Other accounts contrasted the artificiality of Broadway with Black America's perceived naturalism, noting that "Mr. Sals- 
bury's negroes do not 'make up,' they do not strut or strain after effect. They are as the Lord made them, full and running over with naiveté and jolly animalism." 18 Salsbury even threatened to dismiss any member of his cast caught "acting," arguing that while white actors can successfully imitate blacks, "no negro that I have ever seen was a success as an actor." To achieve this, he claimed to have hired only southern blacks with no more than "local fame" in their southern hometowns. ${ }^{19}$ None were "show people," he explained to a Boston reporter, but rather "the genuine southern negro in all his types." ${ }^{20}$ Salsbury often emphasized during the course of Black America's run that his cast featured "the genuine southern negro in all his types" and had all been handpicked from southern farms and plantations in Virginia and North and South Carolina. Similarly, he had insisted that his cast of Indians in the Wild West Show be "only of the purest blood, the best representatives of the most famous and warlike tribes." 21 The entertainment value lay in the re-creation of a culture "lost" to time and the demonstration of black plantation life. As audiences explored the "plantation"- life in the slave quarters and typical forms of plantation labor-they could engage the pageant's African American residents and laborers in a discussion about their lives in the South and, for the older "actors," remembrances of their lives under slavery. In the evening, the amphitheater show contradicted Salsbury's claims, as the performers dressed, sang, danced, and marched in ways that were said to be characteristic of slavery days.

Debuting on May 25, 1895, audiences for the evening performance regularly exceeded the amphitheater's 7,000- or 8,000-seat limit, reaching a recordhigh attendance by the end of the month with an audience of 15,000 and averaging an almost-full house nightly during its premier New York run. ${ }^{22}$ What imagined "loss" did the pageant's nostalgia satisfy for its white northern audience, most of whom, as the press regularly noted, had had no firsthand experience with the U.S. South? Foremost, Salsbury depicted blacks as active participants in the drama of "civilization," likening their history to recent immigrants to the United States, within a narrative of "choices" and opportunities rather than coercion. As with the Wild West Show, Salsbury created commercial and civic tie-ins with Manhattan by organizing parades down Fifth Avenue, a public serenade outside the mayor's office, and special theme days that linked the lives of New Yorkers, black and white, to his picture of the South and to the economic future of the nation. ${ }^{23}$ Salsbury had done something similar in 1886 when he hired a dramatist to write "The Drama of Civilization," a production for his Wild West company that capitalized on the unveiling of the Statue of Liberty in New York. In his black pageant, African Americans appeared to be similarly "pacified," interpellated into a hegemonic national project and racial order-the nation's "civilizing" mission. The marker of success, even more for Salsbury's blacks than his "Indians," was that the coercive power of white hegemony remained invisible. The mainstream press as well was crucial in constructing the Wild West and Black America as dramas of civilization. Salsbury was a great patriot, they argued, having "done the government a great good" with his work 
with the Wild West Indians. Not only did he teach them to appreciate the power of whites and accept them as "a good friend," but he instilled in them the civic importance of owning and accumulating property. Salsbury agreed that Wild West had "civilized" his show Indians, evidenced by the fact that not one former member of his Wild West cast had taken part in the Sioux revolt at Pine Ridge but had instead established farms and cultivated "ambitions and a respect for the rest of the world." Salsbury's blacks, too, one commentator noted, are "learning the advantage of independent prosperity." 24

Like the Wild West Indians, Salsbury argued that his black pageant performers had developed a solid work ethic under his disciplined management. Every one of his black pageant workers, he noted, "has a contract in his pocket." ${ }^{25}$ In mid-June, he invited members of the New York Cotton Exchange, including its president, Reinhard Seidenburg, to attend a special evening concert by his cast. ${ }^{26}$ Among the city's earliest futures traders, the New York Cotton Exchange was charged in 1870 with furthering "the marketing of the southern cotton crop during [a] period of uncertainty and speculation" and helped to salvage the postbellum cotton industry. Seidenburg's organization and other exchanges had, by century's end, played a major role in innovating, nationalizing, and globalizing the cotton market by serving as a link between cotton production in the U.S. South, futures trading in New York, and mill production in New England and Liverpool. More than picturesque, Salsbury's "cotton field" functioned to visually link New York City with the U.S. South and the global market, giving New Yorkers a "valuable idea" of just how important the South's cotton industry was to New York and the nation. ${ }^{27}$ Black America's retreat into history had an implicit economic message for the present as Americans in the 1890s sought to emerge from a struggling economy: with New York's help, the South would ride out the impending loss of its most reliable labor force and continue its crucial regional partnerships within the global commercial trade of southern products..$^{28}$

Salsbury's black "cotton-ginners" were also central to making these epistemological links between regional reconciliation and national destiny, reinserting people and places that existed "out of time" and space into the present moment. Six former slaves demonstrated old-fashioned methods of cotton baling using a century-old Virginia cotton gin. In a largely unremarked on but important irony, the heart of the nation's cotton production was now in the Deep South rather than the overworked and exhausted cotton farms of the Piedmont region from which these men hailed. ${ }^{29}$ Furthermore, the pageant's celebration of black agricultural labor in the South was a reaction to a growing white panic about the out-migration of blacks in the South. Although historian George E. Haynes noted as early as 1912 that African Americans flocked to urban areas for the same reasons as whites - better jobs, educational opportunities, and excitement—black migration in the 1890 s was constituted as a social problem with serious implications for southern agriculture. ${ }^{30}$ Unlike white immigrants, however, black migrants were deemed "incapable of reform," provoking a se- 
ries of moral reform campaigns that historian Marcy S. Sacks has documented in her social history of pre-Harlem black New York. In her study, Sacks argues that urban moral reform campaigns as well as vaudeville and Tin Pan Alley's mass commercialization of "coon" stereotypes depicted black migrants as inappropriate and unassimilable, notions that directly impacted popular perception of black migrants. Under such intense scrutiny, public policy directed its sights on isolating and "reforming" the city's African Americans. ${ }^{31}$

The rate of black migration in the 1890s was small compared to the Great Migration of the interwar period of the twentieth century, yet the pageant addressed the need for blacks to remain in the South, where their labor could advance the nation's industrial agricultural strength. Salsbury's nostalgic plantation was not simply about the past; rather, it constructed a coherent narrative about black labor in the cotton industry, as historically and contemporaneously central to the nation's economic success in the era of industry and futures. If black labor could be recollected historically, in its "rightful" place and time, only then might its value to the present be comprehended. As one contemporary remarked, Americans should take greater interest in Black America than the Wild West Show since black southern laborers "mean more to the North" than Native Americans. "The South," he noted, "is developing a very lively competition in all sorts of business." ${ }^{32}$ Situating blacks' importance to the national economy as southern laborers functioned tacitly to discourage blacks from migrating to cities like New York, a matter of grave concern for African American leaders as well as white southerners. In a futile effort to stem this northward tide, Howard University professor Kelly Miller warned members of his race that there was "no industrial raison d'etre" for them in the North. White industry refused to hire blacks and once there, he implored, blacks would inevitably "form the dregs, the scum, and menace of municipal life." ${ }^{33}$ Salsbury's pageant made southernness intrinsic to African American identity by reattaching race to region not simply by celebrating southern black culture but by actively interpellating black New Yorkers into an essentialist notion of blackness as southernness. Once again, Salsbury made this point with another theme day. On June 19, papers publicized would present "Pickaninny Day" at the Black America. Black women in New York City were called on to showcase their babies on the show grounds, and papers reported that roughly 1,000 infants were to partake in the "Grand Exhibition of Colored Babies." ${ }^{34}$ Although promoted as a women's interest event, Salsbury's theme day really functioned in a tutelary manner to discipline African American identity: according to this logic, all black babieswhether born in New York City or South Carolina - were (or remained, as the logic held) essentially "pickaninnies." Here, race making was shown to be a public, participatory, and popular action. Nonprofessionals were incorporated into a semiprofessional pageantry, and yet again, Salsbury's supersized baby promenade relied on scale and repetition to put forth its conception of blackness. 
Following a brief run in Boston, the pageant returned to Madison Square Garden in New York in September 1895. Now an indoor show, Salsbury "revivified" the program with the inclusion of emerging African American leader Booker T. Washington's most famous speech delivered that summer at the Atlanta Cotton States Exposition. The foremost conciliatory statement by an African American southerner toward a white southern audience in its time, the Tuskegee University president instructed members of his race to "cast their buckets down" where they were. Rather than try one's luck in the North or in unfamiliar educational fields, blacks should run their own businesses, purchase land, and manage their own farms in the South. Like Miller, Washington reminded blacks that northern discrimination existed, especially in an industry that repeatedly passed over blacks in preference to European immigrant laborers. Washington's popularity in the North was complicated because of his rapidly growing power among whites, but many educated blacks in the North quietly bristled at his championing of industrial education to the neglect of sorely underfunded black schools and to the intransigent discrimination of white educational institutions. Washington's speech gave white southerners permission to continue to defund black schools in favor of industrial and agricultural education for blacks and to sacrifice black social and political equality. Ignoring black disfranchisement and the rising tide of antiblack violence in the South, Washington insisted that southern whites were the Negro's friend. "In all things that are purely social," he intoned, "we can be as separate as the fingers, yet one as the hand in all things essential to mutual progress." Washington's program of racial conciliation fit easily within Salsbury's reconciliationist vision for Black America with many African Americans finding much to celebrate in Washington's ethic of hard work, self-help, and self-sufficiency. ${ }^{35}$

Complementing Washington's insistence that the South was the true "home" of the black folk, the press indulged its reader with stories about the show ground's naturalist setting of black antebellum life. In their "little world," reporters noted, the cast moved about as if the show grounds were indeed their natural habitat: one woman "calls" on her neighbors in nearby cabins while a man saunters leisurely "on errands bound." The majority remained inside the "colony," one reporter noted, and spent their time "loafing about, or sleeping, chatting or playing cards, really living a life to which their race must be ideal in its well-fed freedom from responsibility, and its daily gratification of simple, honest vanity." Similarly, the black actors were characterized as if their lives had changed little since the days of slavery. Direct from southern plantations and fields, the cast "present[ed] animated scenes of rural simplicity in Dixie, among which they were born and brought up." The writer continued, "In 'Black America' the true Southern darkey is seen just as one might see him in a journey to the land of cotton through a car window." ${ }^{36}$ The pageant conformed to changes in modern tourism, which, as Richard H. Gassan has argued, promised the "illusion of novelty" while making blacks safe for white consumption and offering visitors the unique experience of an idyllic southern landscape while 
reassuring them with the image of the security and distance of a car window. ${ }^{37}$ Looking through this metaphorical window, the white audience was as instrumental in stabilizing the meaning of the production as were the black actors and performers themselves.

Nate Salsbury, too, found a place within this antebellum fantasy, depicted by the press as a stern but benign, modern-day slave master. The truth of his background, however, was far different: Salsbury was born into a lower-class family in rural Illinois and escaped an abusive stepfather by enlisting in the Union army at the age of thirteen. By sixteen, he had left army life behind and eked out a living as a gambler and business school student and eventually becoming the successful head of his own blackface minstrel troupe. His interest in Black America came out of his love of minstrelsy for, he noted, "I believe the negro voice is the most powerful, sweet and resonant organ possessed by any member of the human race. Furthermore, he has a remarkable sense of rhythm, and in both singing and dancing he is delightful." ${ }^{38}$ Black America's well-disciplined company seemed the product of not only Salsbury's solid business practices but also his "martial" manner and militaristic discipline. Embracing the role of the beneficent but stern slave master, Salsbury claimed that " $[\mathrm{t}]$ hese people are no more difficult to manage than other people." Well treated, they were required only to attend to their business in the company and to "behave decently." He added, "If they don't care to do that, we set them right out. There's no argument, no chance for it." ${ }^{39}$ That social uplift mission, as Salsbury saw it, required him to maintain constant control over his vision of the pageant as a unique blend of the didactic and the pleasurable, as celebration and as social work, as a form of "ethno-tainment" that paralleled the assumed "love and theft" that he had practiced as a blackface minstrel. Black America engaged in a form of "black fun" that, as Eric Lott argues, reflected an "ambivalent attitude toward enjoyment" rooted in the industrial morality of the nineteenth century. ${ }^{40}$ This form of black plantation fun expressed at once an escape from industrial modernity through the bodies of blacks and an admiration for a black efficiency and orderliness befitting an industrial society (didactic not only for northern blacks but, one imagines, for European immigrants as well). As the anachronistic master of his own Brooklyn slave plantation, the northern press helped to promote Salsbury's image as the "American manipulator," a showman who did double duty as an assimilator of the "unassimilable," a benign antebellum plantation baron with the firm manliness of a Civil War army general and the managerial skill of a modern captain of industry.

Salsbury's veil of verisimilitude permeated the press coverage of the pageant to such a degree that the press treated the "non-acting actors" in Black America and the personalities around the pageant as if the show's authenticity mirrored the authenticity of their lives "offstage." Critics rarely conceded that the performers had other identities away from the pageant grounds. To do so would suggest not only that slavery was a regime that relied on "natural" behavior rather than violence and coercion; it would deprive turn-of-the-century 
whites of a national narrative that reinforced what Jayna Brown has described as "the terms of contact and sets of exchange making up [and grounding] ideas of race." ${ }^{\text {"41 }}$ In a prime example, the New York Times noted that "[t]he negroes [of Black America] give no thought for the morrow, and live in their cabins as though life were a continual summer and they were born especially to enjoy it." ${ }^{42}$ By depicting Black America's cast as incapable of "guile" and "burlesque," as essentially "non-actors," ${ }^{43}$ the press actively disavowed their skills as performers and the performative component of the pageant as a whole. This narrative of a "continual summer" of black carelessness denied the performers an awareness of their growing status as stage professionals in a period where blacks were emerging as a regular presence on the popular stage. Turn-of-thecentury African American vaudevillian Tom Fletcher noted in his memoirs that an important and often overlooked outcome of Black America was that it helped to create the first generation of African American vaudevillians. ${ }^{44}$ Among this new generation of blacks pioneering careers on the stage was the pageant's stage manager and performer Billy McClain, whom the Clipper, New York's theatrical trade publication, described in 1898 as having "trained more colored people for the stage than any other man in his line. ${ }^{" 45}$ Not only did McClain serve as a recruiter and manager for Salsbury's pageant, but he also rehearsed the performers, conducted the choir, and, Fletcher suggests, may even have been a key source for the concept that Salsbury ultimately produced. A performer, author, songwriter, and producer, McClain had already written comic sketches and performed in three plantation-themed productions from the 1890s-The South Before the War, The Suwanee River, and Darkest America - before coming to Black America. McClain's involvement in Salsbury's pageant was significantly greater than Salsbury ever gave him credit for, and it was his own professionalism as a seasoned performer that enabled the pageant performers to achieve the "naturalism" that Salsbury sought. McClain later credited himself with the idea behind the pageant and its management, noting,

I can handle hundreds with more ease and better results than I can smaller production[s] of forty or fifty. . . . Why, I've had charge of these and similar productions for years and it seems quite easy. I experienced the same results with "Black America" which by the way, was the most stupendous thing of its kind ever attempted by and for colord [sic] people. ... [I]n successfully staging and producing the last named play I conclusively demonstrated my creative and executive ability. ${ }^{46}$

Even as reviewers sometimes used the term "performers," they went on to note that the "decided feature" of the show was that it was "a continuous performance without the performers being aware of the fact." ${ }^{\prime 7}$ Certainly they were aware, as one witness noted, that there was indeed a difference "between doing 
things naturally and doing them on purpose." In spite of the negro's "deep love of show," there was in fact a crucial distinction to be made, he noted, between amateurs and professionals, and "[n]o one who feels himself to be on exhibition can help showing the feeling a little.... These poor people from the plantation have not had great experience, and they feel all the time that people are looking at them." Observing that some performers kept "their eyes painfully to the front and count their steps," he insisted that self-consciousness will inevitably "find its way in." ${ }^{48}$

Because of the presumed absence of artificiality, local papers insisted that Black America was not a minstrel show. Decrying the overuse of the term "minstrelsy" to describe every type of act in vaudeville, the Brooklyn Daily Eagle pronounced that "[n]egro minstrelsy has grown threadbare under the wear and tear it has been subjected to during the last decade." ${ }^{49}$ Salsbury's production was instead a "Southern spectacle" that contained no burlesque: "Everything that is seen represents part of the daily life of the Southern negro. He is without guile, but he knows how to enjoy himself." ${ }^{50}$ From ethnology to mass commercial culture, visitors went from a living museum to a large-scale variety show that capitulated to popular commercial tastes. Here, they enjoyed an evening of dance, music, boxing, and equestrian demonstrations, various choreographed spectacles, and, on furlough from Indian Territory, the colored division ("Buffalo Soldiers") of the Ninth Cavalry, who represented black military heroism as Indian fighters out West. Riding atop Kentucky thoroughbreds, the cavalry performed "a musical ride and drill" while colored boxers reenacted a "grand assault at arms" and colored jockeys simulated a cross-country ride. African American women also featured prominently in the athletic feats: a group of female equestrians performed on horseback, an "amazon drill" featured women in choreographed marching formations, and women as well as men competed in 150-yard footraces. With a Bible under his arm, William Jones, the principal "exhorter," rode in on a mule to lead the old-time southern "camp meeting" where religious mourners fell to the floor while "raslin' wid de sperit" and slipping into trances. To provide contrast, a "dozen unregenerate youth" were stationed nearby engaged in a craps game. ${ }^{51}$ "No attempt was made at costuming," an observer noted, "and the negroes appeared just as they do in the cotton patch or kitchen." The performers executed precision marching drills with men dressed in their homespun and straw hats and the women clad in kerchiefs and calico dresses. Newspapers reserved the vast majority of praise for the unique choral singing, whose sad beauty was a novelty to white northerners. Agile folk dancers performed the buck and wing and clog dances while cakewalking couples humored the crowd with ornate moves and fancy high stepping. One critic described the impact of the dancing on northern audiences in the following manner:

During the second act a band of pickaninnies come tumbling in, with the typical seatless trousers, crownless hats and bare 
feet. Old Jeb Andrews, a product of the early 30 s, with snowwhite hair, picks up his banjo and starts a rattling jig that sets your feet to keeping time. Then the finely formed and strong colored boys, who but a moment before were sprinkling jig sand to the words of a darky melody, begin to dance. No such dancing has been seen on any stage before. ${ }^{52}$

"There is no burlesque in Black America," critics insisted, but instead a rare opportunity for blacks to present themselves as entertainers in a dignified manner. ${ }^{53}$ However, those moments when the naturalism of the village gave way to racial burlesque during the amphitheater show interrupted Salsbury's purified vision of black antebellum life.

In less self-conscious moments, the pageant's black performers sometimes managed to enjoy what seemed to be a more authentic experience of cultural community. One observer noted that it was clear "that the performers themselves seemed to take an unusual interest in their [own] work." ${ }^{54} \mathrm{At}$ such times, the meaning of Billy McClain's recollection that the pageant was "the most stupendous thing of its kind ever attempted by and for" African Americans acquired greater clarity. One account of the dancers' circle, for instance, suggests that the black hoofers often danced for each other, enjoying a shared cultural experience outside the demands of their audience. Although he credited the graceful and easy movement of the dancers to their "untrammeled outdoor life," one witness captured a moment that could not be replicated on the minstrel stage:

Old and young, male and female, all dance as inclined, and produce an effect that is wonderful. They dance the "heel and toe," "flim flam," "buck," "wing," and other dances to music of their hands in rhythmic clapping and a low whistle that sounds like "a-whip, a-whip, a-whip, a-wee" in a dull monotone..$^{55}$

Clearly, the dancers observed and learned from each other in spite of the antebellum racial fantasy woven around the pageant and the long shadow of minstrelsy's "white fun" at blacks' expense. For reasons such as this, Salsbury and the press ensured that the public understood that his pageant was not a minstrel show but a production featuring, as his ads noted, "ALL BLACKS-NO WHITES!"'56

At the same time, however, the production's success relied on a disavowal of its relationship to the commercial industry - blackface minstrelsy, Tin Pan Alley, and vaudeville. Those features considered to be inauthentic, notably the "specialty" (i.e., vaudeville) acts, elicited complaints from local papers because they were not considered "characteristic" of black southern folk culture. Indeed, the local press functioned as co-collaborators in Salsbury's mission to depict a "naturalistic" antebellum plantation setting. Many of the performers 
with specialized skills - black jugglers, acrobats, and contortionists among them-became the targets of such criticism and were quickly jettisoned from the program. The Sun (New York) complained that the impact of the variety acts was not only ineffective in such a huge amphitheater but could be found in any vaudeville theater. "Black faces," one reviewer noted, "or the fact that the performers are negroes, do not make a performance characteristic." The female "amazon march" and the equestrian quadrille also, he felt, failed the authenticity test. Rather, the "genuinely negro" features, like the dancing and singing, evinced a naturalism that the specialties lacked. ${ }^{57}$ The African "jungle" scenes of the Dahomians, the supposed "starting point" of the narrative of racial progress, also smacked of inauthenticity. The march of the Dahomey women warriors, another critic noted, was hardly typical of southern life, and "the public would have been glad for more singing and dancing." ${ }^{\text {8 }}$ Rather, the "genuinely negro" features, like the dancing and singing, evinced a naturalism that the specialties lacked. ${ }^{59}$

Despite such claims to authenticity, the legacy of minstrelsy could not be suppressed, and audiences demanded styles of performance rooted more in blackface minstrelsy than in southern plantation life. The theater critic for the Spirit of the Times boasted of his paper's ability to shape the content of the amphitheater show. "We have already suggested the addition of a cakewalk to the bill of fare," he crowed, "and we think that there should be more of the chorus singing, which is very effective." The cakewalk included in the program, however, was a comic cakewalk, and while it proved to be the most talked about comic feature in the program, it revealed that blackface minstrelsy continued to be a popular draw for Black America's audiences. ${ }^{60}$

Some African Americans resented what they saw as racial caricature. Complaining that "his race was being burlesqued in the cake walk," police ejected one African American man from the audience after his loud protestations. ${ }^{61}$ Still, local papers described the cakewalks as eliciting "shouts of laughter each evening." ${ }^{2}$ Salsbury's nostalgia suggested that urban and northern life had "spoiled" something essential and authentic in African Americans and insinuated that urban blacks were "inauthentic" representations of "black America." There were still other instances where the cracks in the edifice of Salsbury's racial fantasy emerged publically.

\section{"[T]he Finest Scrap That Ever Was on Bleecker Street": Disciplining Urban Blackness}

In her social history of pre-Harlem black New Yorkers, Marcy S. Sacks documents that, as early as 1892, white New Yorkers began referring publicly to African American migration into New York City as a "great exodus," complaining that the South's "negro problem" had now become a Yankee problem. ${ }^{63}$ When one reporter reviewed Black America by following two very different social types into the pageant ground - an elderly ex-slave who attended with 
his "old marster" and a youthful pair of gum-chewing white Bowery girls-he sought to offer his readers a contrast between urban types (albeit white) and the old "darkey" celebrated by the pageant. As if to reinforce the idea that the older type of black truly missed slavery days, the ex-slave reportedly informed his former master - over the choir's rendition of "I'se Gwine Back to Dixie""Mars Willyum, I'm gwine leave you folks an' go back Souf." Black America's idealization of southern antebellum space - what Paula Massood has referred to as an "antebellum idyll" - asserted itself as a preferred narrative, one that patently ignored the real story of black migration to the urban North. The trope of the antebellum black South as a "heavenly" space of leisure and plenty would shape popular entertainment into the era of the all-black films of the 1920s and 1930s. As African Americans streamed into northern cities during the Great Migration in this period, their identities as black urbanites was erased in popular entertainment. ${ }^{64}$ During the same visit, another African American contradicted such views by breaking through the racial cordon sanitaire of the pageant. Outside his cabin, the elderly cast member responded to a reporter's question about his origins and answered in a manner that decidedly went against the pageant's official transcript. He hailed from "Po'tsmouth, Faginny" and added pointedly that he had no intention of returning to the South, insisting that "[d]is is de country fur dis nigger." ${ }^{\circ 5}$

Black America also contained a political message for African Americans in the urban North, an instructive tone that can be gleaned from the New York Times coverage of the cast's promotional parade in Manhattan the summer of its Ambrose Park run. The Times reporter observed, "The parade attracted great attention, particularly from the colored people of this city, who thronged the sidewalks and crowded into the gutters along the line of the parade from start to finish." ${ }^{\circ 6}$ Without explaining what black audience members found so compelling about the parade, the reporter suggests that they were curious about the southern quality of these members of their race. From food to dress to forms of worship, the small but growing number of African Americans moving into New York City in the 1890s transformed the city with their southern style of life, talk, and dress. ${ }^{67}$ Was the excitement of the black crowd rooted in the pride of seeing members of their own race in such a highly regarded production, one that depicted "real" blacks as skilled military men and performing artists rather than white minstrels in blackface? Or did they still recognize before them some of the most degrading and embarrassing stereotypes of blackface minstrelsylarge black "mammies" in kerchiefs and big black "bucks," as the press described them? Were they curious about the peculiarities of southern African Americans who, though black like them, remained a cultural novelty? Or were they migrants from the South themselves longing for a lost sense of community or looking on disdainfully as they recalled their former identities as "country bumpkins"? The novelty of the scene may have lain in the distinction that the pageant parade implicitly drew between the show's southern cast and "New York" or "northern" blacks. Promotional ads not only insisted that the show 
contained no whites, but the local press reassured readers that the cast contained none of the "city negroes" characteristic of their Manhattan neighborhoods. ${ }^{68}$ "[I]t will not take the visitor long," the Evening Telegram insisted, "to discover that the Afro-American of the North is an entirely different person from the merry field hand of the cotton belt who, except for his freedom from bondage is much the same light-hearted, simple-minded philosopher that he was 'befo' de Wah." ${ }^{69}$ Another insisted that the Black America negroes "are like the negroes of 'Uncle Tom's Cabin' and not a bit like Northern colored people." ${ }^{.70}$ Supporting this statement with the observation that the performers had built their own village of log cabins, the writer asserted that they "are living exactly like they did on the plantations where they were born." ${ }^{\prime \prime 1}$ These blacks were different, they maintained, having "little in common with his Northern brother" and making him "of much more interest" to northerners since "some of the characteristics of slavery still cling to him." $" 72$

Why was this distinction important to white urban audiences in Manhattan, a city where the African Americans population numbered little more than 30,000 by 1900 and only a bit more than 60,000 after the incorporation of nearby boroughs? In the absence of a real numerical "threat," African American New Yorkers served as an unusually salient target that whites structured in opposition to what they believed to be the "real" negroes: southern, rural, deferential, hardworking contributors to the national productivity. The pageant's translation of ideas about racial hierarchy had little use for subtlety or complexity in its crafted fantasies of race and space. The pageant fed the desire for racial clarity in a period of demographic upheaval in northern cities like New York, a period when the unclear racial status of eastern and southern European immigrants led native Americans to question established concepts of "whiteness." Despite its small scale, African American migrants were a rapidly growing presence in New York City in the 1880s and 1890s, but their increasing visibility as a race stood as a marker for the larger demographic threat of difference transforming cities like New York.

The emphasis on the "characteristic" qualities of southern black performers was a critical and direct statement about the disturbing presence of African Americans in New York and other northern cities. The stereotype of the dandified, criminal-minded black man who loitered on city streets was precisely the "northern negro" whose racial authenticity Black America challenged, diametrically opposed to the authentic plantation throwback. The stereotypical violent black libertine of the urban North and large-scale denial that racial performativity was central to the success of Black America come together in the story of a New Year's Eve "race war" in lower Manhattan. As they rang in the new year, a group of African American men whose nicknames - "Pete the Pig," "The Warbler," and "Black America"-suggest that they were among the "well-known and appropriately named colored denizens" of lower Manhattan noted by the New York Times, waged a pitched battle against neighborhood whites. The "strongly impregnated" feeling of animosity between the area's 
different racial and ethnic groups, the press noted, was like a keg awaiting a match, requiring only "slight provocation to start a miniature race war at any moment of the day or night." "73 As the press told the story, a group of black men terrorized the white clientele and staff at Pell's restaurant on Bleecker Street. Blowing their horns loudly, they entered the restaurant and told the clientele that if they did not like "colored society," they could leave. In an effort to eject them, the white staff threw pots of hot grease at the men, and soon furniture and bottles flew between blacks and whites. Approximately 300 to 500 "frenzied" blacks (and fifty whites) crowded into the street in front of the restaurant, some joining in the fight and others urging members of their race to "kill the white trash." As "Pete the Pig" told the story, he described how he and his friends entered the restaurant hoping to be served and then blew their horns

\begin{abstract}
... just to show him who we was, and then he got mad and told us to be quiet, as ladies was eating. They wasn't colored ladies, and so we blowed again, ... . [w]e didn't do nothing to them, oh, no. I just picked up a little red-headed waiter and dropped him in a plate of beans that a white fellow was eating, and Black America shied a bottle of ketchup at old Hoffman's head and took the front out of his glass door. Then we didn't stop to pick out nobody, but went for every white man in the place.... It was the finest scrap that ever was on Bleecker Street and we had the biggest audience in the city. ${ }^{74}$
\end{abstract}

When the white owner tried to eject them, "Pete the Pig" recalled, "We was just ready for that, and the fracas was right on the spot." The narrator's suggestion here is that Pell's did not, as a custom, admit blacks into their restaurant, according to New York City's widespread but "silent" practice of de facto racial discrimination. The previous year, New York's legislature quietly passed a civil rights bill sponsored by State Senator George Malby making racial discrimination punishable by a fine of $\$ 500$. Charles W. Anderson, the senator's African American assistant, brought the bill to the senator in an effort to address the quiet discrimination that blacks faced in New York City restaurants, bathhouses, and similar businesses. When a small group of African American men announced their intention to test the law by visiting white businesses, they were criticized as rabble-rousers and mercenaries, destroying white businesses by forcing themselves into places where they were not welcome. ${ }^{75}$ Three members of the Douglass Club, a social club of young African American men and an institution that represented the changing face and future of black New York, set out to test the law. Many of the club's members were recent arrivals to the city, and the club contained several vaudevillians and musicians, a representation of the new generation of black semiprofessional performers who were getting their start in the Black America show. 
White businessmen exploded over the "Malby Law," threatening to disobey the law and face consequences rather than lose white customers who refused to be accommodated next to African Americans. Amidst this uproar, Black America's celebration of black civic and economic achievement was a paradox. Some individuals, however, made the connection between Salsbury's arguments about African American progress and African American New Yorkers' assertion of equal rights. Even as the Spirit of the Times extolled the pageant's black singers and dancers, the New York paper dismissed this assertion of African American equal rights, noting,

We do not see why Nate Salsbury ... should not take advantage of the present craze for the assertion of equal restaurant rights and ... dispatch members of the Black American troupe to dine at Delmonico's and the Waldorf for advertising purposes. . . A All the daily newspapers would fall into the trap, as they recently did when two or three Afro Americans started out to advertise themselves. ${ }^{76}$

The commentator's tongue-in-cheek dismissal of the three African Americans who set out to test the law equates their struggle for civil rights with both a trendy fad and an "advertising" strategy. But only a few years later, black New Yorkers would be given a clear and violent message that they were unwanted in the city. In August 1900, at least 10,000 angry whites set upon African Americans on the street and public transportation, targeting African American vaudevillians but attacking anyone within reach in an effort to vent their anger at the growing presence of blacks in Manhattan's white, working-class West Side. While only a handful of whites saw the inside of a jail, blacks crowded into police cars, local jails, and courtrooms to defend their presence on the city's streets. Since the colonial era, the demographics of New York City were changing, making it significantly "blacker" than ever before. Despite the popularity of black cultural forms in the popular culture industries, the physical presence of southern African Americans - their outward manifestations of personal expression and upward mobility — proved threatening to the whites around them. ${ }^{77}$

"Pete the Pig's" forthright account of the ruckus that his gang raised is remarkable for the clarity with which he clearly described it as a fight of black against white as well as the raucous pleasure that he took in the attack. His choice of the word "audience" suggests that his gang considered their actions a type of racial performance, one aimed not only at the whites who exerted proprietary claim over the public and private space of the neighborhood but also as a demonstration of power on behalf of their black neighbors as well who served as a supporting cast as they cheered outside the restaurant. His account suggests that the destruction of the restaurant was an event of record for the African Americans of lower Manhattan. "[H] ow our friends did cheer!," "Pete the Pig" boasted. "They wanted us to do them, and we done them." Their disre- 
gard of the white "ladies" in the restaurant ("They wasn't colored ladies, and so we blowed again") reveal an indifference to white-dominant rules of etiquette in favor of racial solidarity. They clearly relished this show of resistance to white dominance - showing them "who we was"-an anarchic response both violent and humorous, as seen in their attempt to "liberate" the restaurant of its flatware and their raucous destructiveness. Black America's racial performances aimed to encode black America with a nostalgic fantasy of southern "darkies" with an "authenticity" (and thus authority) challenged by the black revelers on Bleecker Street. In contrast to the Black America village performers as imbued with a "kindly family and neighborly affection," the more assertive "black America" of the urban North seemed to be encoded in the adoption of the nickname "Black America" by William Litt, one of the Bleecker Street rioters. Urban black identities in turn-of-the-century Manhattan were volatile, anarchic, and antiauthoritarian, and their sense of authority came not from their southern identities but from their demands for recognition within their own urban milieu. Clearly, they intended to stay and fight.

The pageant's symbolic address to the real African Americans in the city sought to correct black behavior. In its shaping of historical narrative, Black America put forth a vision for the present: that the "errant" racial performances of urban northern African Americans could, like that Native Americans in the West, be "pacified" and domesticated. Salsbury's "great sociological exhibit" depicted antebellum blacks as carefree and childlike - "when he didn't have to take care of himself but was cared for as children are"-but concerned itself foremost with managing those black urban subjectivities that refused to conform to this dominant white, middle-class vision. As working-class and poor blacks began to demand recognition and access to the city, they increasingly and more openly evinced an unwillingness to subordinate themselves to white control, beneficent or not. ${ }^{79}$ "Black America's" adoption of the pageant's name suggests that Salsbury's production had contradictory effects: it demonstrated how cultural pageantry and performance aided the nation's "civilizing" mission and modeled the rewards of sectional reunion and economic cooperation but also revealed how cultural performance was capable of empowering African American New Yorkers rather than pacifying them. Although the press saw the pageant as a means to familiarize whites with the "new" Negro - to interpret this figure as a modern worker and a voter, as the commentator cited above suggested - they were unwilling to understand those African Americans just outside their doors. ${ }^{80}$

\section{Notes}

The author would like to thank the editors and staff of American Studies, the generosity of the article's known and unknown readers, as well as the staff of the Billy Rose Theater Collection at the New York Public Library for access to the Billy McClain folder and Yale University's Beinecke Library for access to the Nathan Salsbury scrapbook. The archival location of the Billy McClain folder will be denoted as "BRTC/NYPL" in the notes. 
1. Quoted in Lynn Abbott and Doug Seroff, Out of Sight: The Rise of African American Popular Music, 1889-1895 (Jackson: University Press of Mississippi, 2003), 391.

2. "Walks about the City," Brooklyn Daily Eagle, June 2, 1895, 8.

3. Clipping, New York Daily Mirror, July 1895, Billy Rose Theater Collection/New York Public Library; "Wild Negro Chants and Dances," New York Times, May 25, 1895, 9; “A Trip to Black America," New York Sun, June 9, 1895, 5. Hereafter the Billy Rose Theater Collection/New York Public Library will be referred to in the notes as BRTC/NYPL.

4. While the pageant has received frequent mention in a number of scholarly works, few researchers have devoted significant attention to the content, reception, and legacy of Black America. One of the earliest was Roger Allan Hall's article "'Black America': Nate Salsbury's AfroAmerican Exhibition," Educational Theatre Journal 29, no. 1 (March 1977): 49-60. More recently, Barbara L. Webb has looked at the pageant as central to the emergence of "plantation performances" in the popular theater of this era, many of which incorporated the generation of black performers who transformed vaudeville and Tin Pan Alley in the 1890s and into the 1910s. Webb argues here that black participation in such productions should be characterized not by the limitations placed on black performers - in other words, their inability to bring African American cultural forms to the stage in an authentic, nonburlesqued manner - but as a field of opportunity for African Americans. See Webb, "Authentic Possibilities: Plantation Performance of the 1890s," Theatre Journal 56, no. 1 (2004): 63-82. Finally, Lynn Abbott and Doug Seroff have provided useful newspaper sources discussing the pageant in their chronicle of black entertainment, Out of Sight.

5. Clipping, "Black America," Billy McClain folder, BRTC/NYPL.

6. "Scenes in 'Black America," New York Times, May 26, 1895. A biographical sketch of Billy McClain sets the size of the cast at 865, a figure that is larger than any others I have encountered and that may possibly refer to the original cast and staff as well as the touring cast. Zeke Blossom, "Comedy Genius, Billy McClain," Billy McClain Clipping File, BRTC/NYPL.

7. "Black America," Brooklyn Daily Eagle, June 11, 1895, 2.

8. Michele Wallace, "Uncle Tom's Cabin: Before and after the Jim Crow Era," The Drama Review 44, no. 1 (Spring 2000): 136-56.

9. David W. Blight has documented the persistence of such "rituals of reunion," commemorative cultural practices, including pageantry, geared toward the symbolic healing of the divisions between North and South during the post-Reconstruction era and well into the twentieth century. See Race and Reunion: The Civil War in American Memory (Cambridge, MA: Harvard University Press, 2001) and other formative studies of cultural production and sectional reconciliation, including Nina Silber's Romance and Reunion: Northerners and the South, 1865-1900 (Chapel Hill: University of North Carolina Press, 1993); Edward J. Blum's Reforging the White Republic: Race, Religion, and American Nationalism, 1865-1898 (Baton Rouge: Louisiana State University Press, 2005); and Paul H. Buck's The Road to Reunion: 1865-1900 (1937; reprint, New York: Random House, 1959).

10. Susan Stewart, On Longing: Narratives of the Miniature, the Gigantic, the Souvenir, the Collection (1984; reprint, Durham, NC: Duke University Press, 1993), 145.

11. Stewart, 23, 163.

12. Stewart, 23, 80 .

13. Daphne A. Brooks, Bodies in Dissent: Spectacular Performances of Race and Freedom, 1850-1910 (Durham, NC: Duke University Press, 2006).

14. Jayna J. Brown, Babylon Girls: Black Women Performers and the Shaping of the Modern (Durham, NC: Duke University Press, 2009), see esp. 128-29.

15. Kasson says of the Buffalo Bill's Wild West Show, "At stake were not only the invention of a great entertainment form and the creation of a worldwide celebrity, but the forging of a link that would grow stronger over the course of the next century, a link between national identity and popular culture, between Americans' understanding of their history and their consumption of spectacularized versions of it." See Joy S. Kasson, Buffalo Bill's Wild West: Celebrity, Memory, and Popular History (New York: Hill \& Wang, 2000), 8, 72-73.

16. Gail Bederman's well-cited study of manliness and civilization addresses the emerging emphasis on racial "primitivity" as sources for the reinvigoration of white masculinity at the end of the nineteenth century. See Bederman, Manliness and Civilization: A Cultural History of Gender and Race in the United States, 1880-1917 (Chicago: University of Chicago Press, 1996).

17. Clipping, "Black America," August, 1895, Billy McClain folder, BRTC/NYPL.

18. “"Black America' in the City," New York Herald, September 17, 1895, 7.

19. Washington Post, April 23, 1899.

20. "An American Manipulator: How Black America Came to Pass-- Who Conceived It," Boston Transcript, July, 1895, clipping file, BRTC/NYPL..

21. "An American Manipulator"; "Black America's Manager," Philadelphia Record, October $10,195,7$.

22. "Black America’s Biggest Day,” New York Times, May 31, 1895; "Black America’s Great Success," New York Times, June 30, 1895; "Black America Draws," New York World, June 16, $1895,26$. 
23. "Black America to Parade," New York Sun, June 13, 1895, 8; "Black America's Parade," New York Dramatic Mirror, June 22, 1895, 4; "Black America on Parade," New York Herald, June $14,1895,7$.

24. Clipping, BRTC/NYPL.

25. Clipping, Boston Transcript, 1895, BRTC/NYPL.

26. “Cotton Men Enjoy 'Black America,"” New York Tribune, June 15, 1895, 5; New York Times, June 14, 1895.

27. "Black America Draws," New York World, June 16, 1895, 26.

28. "Home of the Cotton Brokers," New York Tribune, January 13, 1896, 3; Kenneth J. Lipartito, "The New York Cotton Exchange and the Development of the Cotton Futures Market," The Business History Review 57, no. 1 (Spring 1983): 50-72; Melvin Thomas Copeland, The Cotton Manufacturing Industry of the United States (Cambridge, MA: Harvard University Press, 1912), 185; Sarah Bradford Landau and Carl W. Condit, Rise of the New York Skyscraper, 1865-1913 (New Haven, CT: Yale University Press, 1999).

29. "A Trip to Black America," New York Sun, June 9, 1895, 5; "Walks about the City," Brooklyn Daily Eagle, June 2, 1895, 8; Copeland, The Cotton Manufacturing Industry of the United States.

30. George Edmund Haynes, The Negro at Work in New York City: A Study in Economic Progress, vol. 49, no. 3 (New York: Columbia University Press 1912), 19.

31. See Marcy S. Sacks, Before Harlem: The Black Experience in New York City before World War I (Philadelphia: University of Pennsylvania Press, 2006), 23, 32.

32. "The Spirit of the Stage," Spirit of the Times, June 1, 1895, 702.

33. Kelly Miller, Race Adjustment: Essays on the Negro in America (New York: Neale Publishing, 1909), 119.

34. Advertisement, New York Sun, June 18, 1895, 10; “Pickaninnies at 'Black America,"” New York Sun, June 19, $1895,7$.

35. "The Spirit of the Stage," Spirit of the Times, September 28, 1895, 356.

36. Clipping, Boston Transcript, BRTC/NYPL.

37. Richard H. Gassan, The Birth of Tourism: New York, the Hudson Valley, and American

Culture, 1790-1830 (Amherst: University of Massachusetts Press, 2008), 4.

38. Clipping, BRTC/NYPL.

39. Boston Transcript, July, 1895, BRTC/NYPL.

40. Eric Lott, Love and Theft: Blackface Minstrelsy and the White Working Class (New York: Oxford University Press, 1993), 148.

41. Brown, 141.

42. "Scenes in "Black America," New York Times, May 26, 1895.

43. For example, a Philadelphia paper noted, "They do not act at all, they simply depict life below Mason and Dixon's line the same as the 'Wild West' illustrates life on the frontier." "Nate Salsbury's Spectacle Returns to the Grand Opera House," Philadelphia Record, November 3, 1895, 14.

44. Tom Fletcher, 100 Years of Show Business: The Tom Fletcher Story (New York: Burdge, 1954), 24, 94-97.

45. "A Popular Colored Comedian," New York Dramatic Mirror, September 3, 1898, 3.

46. Blossom, McClain Folder, BRTC/NYPL, emphasis added. Another account says that McClain "took the darkies in hand" as soon as they arrived in New York and "rehearsed the entire programme" with what were essentially amateurs. See "A Trip to Black America," New York Sun, June 9, 1895, 5. The dignified and well-dressed McClain presented himself as a financially and artistically successful man and was credited in the press for his exceptional managerial skills. "Row at Black America," Brooklyn Daily Eagle, June 14, 1895, 7. I have yet to come across any mention of McClain by Salsbury.

47. "A Trip to Black America," New York Sun, June 9, 1895, 5.

48. "Scenes at 'Black America,"” New York Daily Tribune, June 9, 1895, 12.

49. "Black America Returns," Brooklyn Daily Eagle, September 25, 1895, 6.

50. "Theatrical," Brooklyn Daily Eagle, September 29, 1895, 9.

51. "A Trip to Black America," New York Sun, June 9, 1895, 5.

52. Wheeling (W.V.) Sunday Register, August 4, 1895, 11.

53. "Theatrical," Brooklyn Daily Eagle, September 29, 1895, 9; "Black America," Brooklyn Daily Eagle, June 11, 1895, 2.

54. "Black America' at the Garden," New York Times, September 17, 1895.

55. "Wild Negro Chants and Dances," New York Times, May 25, 1895.

56. Advertisement, New York Sun, May 29, 1895, 10.

57. "Negro Life Depicted," New York Sun, May 26, 1895, pt. I, 7; New York Daily Mirror, June 1,1895 , BRTC/NYPL.

58. "The Actors See 'Black America,"” Brooklyn Daily Eagle, June 8, 1895, 7.

59. "Negro Life Depicted," New York Sun, May 26, 1895, pt. I, 7; New York Daily Mirror, June 1, 1895, BRTC/NYP L. 


\section{Lori L. Brooks}

60. "The Spirit of the Stage," Spirit of the Times (N.Y.), June 1, 1895, 702; “"Black America' Indoors," New York World, September 17, 1895, 4; "“Black America' at Madison Square,” New York Evening Telegram, September 17, 1895, 4; "Black America Draws," New York World, June 16, 1895, 26. "Miscellaneous Bills," New York World, September 22, 1895, 34.

61. "Black America," New York Daily Mirror, July 6, 1895, BRTC/NYPL.

62. "Miscellaneous Bills," New York World, September 22, 1895, 34.

63. Sacks, Before Harlem, 23.

64. Paula Massood, Black City Cinema: African American Urban Experiences in Film (Philadelphia: Temple University Press, 2003).

65. "A Trip to Black America," New York Sun, June 9, 1895, 5.

66. “A ‘Black America' on Parade,” New York Times, June 14, 1895.

67. The notion that the parade's black audience lacked knowledge of black southern culture is untenable. African American migrants did not abandon their southern culture while in the urban North. As early as the 1890s, the black New York Age regularly featured material of interest to black migrants to the South and included ads for black restaurants serving southern cuisine. Historian Gilbert Osofsky has documented the ways by which African American southerners in New York City fought against the loss of their regional roots and imprinted their neighborhoods with black southern culture, from the black churches that catered to southern blacks to the visible black cultural styles and practices of black New Yorkers that reflected their southern roots. See Osofsky, Harlem: The Making of a Ghetto (1971; reprint, Chicago: Ivan R. Dee, 1996).

68. Advertisement, New York Sun, May 29, 1895, 10.

69. “"Black America' at Ambrose Park," New York Evening Telegram, May 24, 1895, 6.

70. “Black America Illustrated," Sag Harbor (N.Y.) Express, June 13, 1895, 1.

71. Ibid.

72. "Wild Negro Chants and Dances," New York Times, May 25, 1895, 9.

73. "Nearly a Riot in Bleecker Street," New York Herald, January 2, 1896; "With Hot Fat and Dishes," New York Times, January 2, 1896, 9.

74. Emphasis added. "With Hot Fat and Dishes," New York Times, January 2, 1896.

75. "Will Test the Law Thoroughly," New York Times, June 19, 1895; "Negroes Not Unanimous," New York Times, June 20, 1895; "Negroes and the New Civil Rights Law," Brooklyn Daily Eagle, June 21, 1895, 6.

76. Emphasis added. “The Spirit of the Stage," Spirit of the Times (N.Y.), June 29, 1895, 858.

77. For more on the 1900 riot, see Marcy S. Sacks and Lori L. Brooks, Ragtime Cosmopolitanism: African American Men on the Popular Stage before the Harlem Renaissance (New York: New York University Press, forthcoming).

78. Unidentified newspaper clipping, Nathan Salsbury scrapbook, Beinecke Rare Book and Manuscript Library, Yale University. See also Tom Fletcher, 100 Years of the Negro in Show Business (1954; reprint, New York: Da Capo Press, 1994), 93.

79. "Black America," Daily Charlotte (N.C.) Observer, June 2, 1895, 5.

80. After a stint in Boston in August, the pageant essentially abandoned the historical pageantry component. Roger Allen Hall noted that, after seven more weeks in Boston and a brief return to Manhattan, Salsbury took his company to seven more cities, including Philadelphia, Baltimore, and Washington D.C. The company disbanded before a hoped-for stint in London. In all, Black America had a six-month run in the United States. See Hall, "'Black America,"” 49, 60. 